\title{
IAPs cause resistance to TRAIL-dependent apoptosis in follicular thyroid cancer
}

\author{
Thomas A Werner1,*, Inga Nolten',*, Levent Dizdar', Jasmin C Riemer², Sina C Schütte', Pablo E Verde, \\ Katharina Raba4, Matthias Schott5, Wolfram T Knoefel1 and Andreas Krieg' ${ }^{1}$ \\ 'Department of Surgery (A), Heinrich-Heine-University and University Hospital Duesseldorf, Duesseldorf, Germany \\ 2Institute of Pathology, Heinrich-Heine-University and University Hospital Duesseldorf, Duesseldorf, Germany \\ ${ }^{3}$ Coordination Centre for Clinical Trials, Heinrich-Heine-University and University Hospital Duesseldorf, Duesseldorf, Germany \\ ${ }^{4}$ Institute for Transplantation Diagnostics and Cell Therapeutics, Heinrich-Heine-University and University Hospital Duesseldorf, Duesseldorf, Germany \\ ${ }^{5}$ Division of Endocrinology, Heinrich-Heine-University and University Hospital Duesseldorf, Duesseldorf, Germany
}

Correspondence should be addressed to A Krieg: andreas.krieg@med.uni-duesseldorf.de

*(T A Werner and I Nolten contributed equally to this work)

\begin{abstract}
Follicular thyroid cancer's (FTC) excellent long-term prognosis is mainly dependent on postoperative radioactive iodine (RAI) treatment. However, once the tumour becomes refractory, the 10-year disease-specific survival rate drops below $10 \%$. The aim of our study was to evaluate the prognostic and biological role of the TRAIL system in FTC and to elucidate the influence of small-molecule-mediated antagonisation of inhibitor of apoptosis proteins (IAPs) on TRAIL sensitivity in vitro. Tissue microarrays were constructed from forty-four patients with histologically confirmed FTC. Expression levels of TRAIL and its receptors were correlated with clinicopathological data and overall as well as recurrence-free survival. Non-iodine-retaining FTC cell lines TT2609-C02 and FTC133 were treated with recombinant human TRAIL alone and in combination with Smac mimetics GDC-0152 or Birinapant. TRAIL-R2/DR5 as well as TRAIL-R3/DCR1 and TRAIL-R4/DcR2 were significantly higher expressed in advanced tumour stages. Both decoy receptors were negatively associated with recurrence-free and overall survival. TRAIL-R4/DcR2 additionally proved to be an independent negative prognostic marker in FTC $(H R=1.446$, 95\% Cl: 1.144-1.826; $P<0.001)$. In vitro, the co-incubation of Birinapant or GDC-0152 with rh-TRAIL-sensitised FTC cell lines for TRAIL-induced apoptosis, through degradation of cIAP1/2. The TRAIL system plays an important role in FTC tumour biology. Its decoy receptors are associated with poor prognosis as well as earlier recurrence. The specific degradation of CIAP1/2 sensitises FTC cells to TRAIL-induced apoptosis and might highlight a new point of attack in patients with RAI refractory disease.
\end{abstract}

$\begin{array}{ll} & \text { Key Words } \\ \text { - } & \text { FTC } \\ \text { - TRAIL resistance } \\ \text { - } \text { CIAP } 1 / 2 \\ \text { - apoptosis }\end{array}$

Endocrine-Related Cancer (2018) 25, 295-308

\section{Introduction}

Thyroid malignancies are the most common endocrinerelated cancers in men (Dralle et al. 2013). Their incidence rates have been steadily on the rise over the last decade, cumulating in a lifetime risk of $1.1 \%$, making it the 9 th most common malignancy in the U.S. (Gruber \& Colevas 2015). Cancers of the thyroid gland comprise different biological entities that differ widely in terms of treatment and prognosis. Follicular thyroid cancer (FTC) accounts 
for $10-15 \%$ of all differentiated thyroid malignancies (DTC) and is characterised by an invasive nature and early haematogenous spread (Hundahl et al. 2000).

The standard of care for these patients consists of radical thyroidectomy with or without cervical lymphadenectomy and postoperative radioactive iodine (RAI) treatment, followed by TSH suppression (Byrd et al. 2012). Overall, this type of cancer is associated with an excellent 10-year disease-specific survival rate of $\sim 85 \%$ (Eustatia-Rutten et al. 2006).

Interestingly, however, the long-term prognosis of FTC patients with advanced tumour stages is vastly dependent on postoperative RAI treatment. While the majority of patients with disseminated DTC are RAI positive, approximately one-third of these patients show no RAI uptake at the time of diagnosis (Durante et al. 2006, Martin et al. 2013, Robbins et al. 2013). In addition, about $25-50 \%$ of patients with advanced tumour stages, i.e. UICC III and IV, will turn RAI negative over their course of the disease, rendering the 10-year disease-specific survival rate below 10\% (Durante et al. 2006, Anderson et al. 2013, Vaisman et al. 2015).

The new appreciation of RAI refractory FTC has caused great efforts in this line of research and led to considerable changes in adjuvant therapeutic regimes. Thus far however, the new multikinase inhibitors could not live up to their expectations (Brose et al. 2014, Vaisman et al. 2015). This absence of an effective second-line therapy leaves an on-going high demand for the identification of relevant signalling pathways that influence the tumours biology and can be used to effectively target FTC. In this regard, TNF-related apoptosis-inducing ligand (TRAIL) and its receptors have gained considerable attention over the last decades. TRAIL's capacity to selectively induce apoptosis in cancer cells caused great enthusiasm in the scientific world and was soon deemed an universal cancer solution (Griffith \& Lynch 1998, Bonavida et al. 1999, Nagane et al. 2001).

Upon binding of TRAIL to the death domaincontaining receptors TRAIL-R1/DR4 and TRAIL-R2/DR5, apoptotic cell death is initiated via the death-inducing signalling complex (DISC). The subsequent activation of caspase 8 and 10 through the adaptor protein Fas-associated protein with death domain (FADD) ultimately steers the cell down the well-regulated steps of apoptotic cell death (Kischkel et al. 2000, 2001, Sprick et al. 2000).

The initial euphoria, however, was soon dampened by the fact that multiple cancer types were not susceptible to TRAIL receptor agonists (TRA) and demonstrated profound resistance in vivo (Todaro et al. 2008). Since then, multiple types of resistance mechanisms have been discovered and counteractions were devised. TRAIL can not only bind to its death domain (DD)-containing receptors TRAIL-R1/DR4 and TRAIL-R2/DR5, but also to the non-DD-containing receptors TRAIL-R3/DcR1 and TRAIL-R4/DcR2. Subsequently, the decoy receptors compete with the DD-containing receptors for ligand binding and can thus impair TRAIL-induced apoptosis when overexpressed (Degli-Esposti et al. 1997, Pan 1997, Mérino et al. 2006).

Other mechanisms of resistance involve the cellular FLICE-like inhibitory protein (cFLIP), which controls the formation of the DISC by competing with FADD for the binding of caspase 8 and 10 (Ganten et al. 2004) and the regulation of mitochondrial outer membrane permeabilisation (MOMP). The MOMP is controlled through a complex balance between pro- and antiapoptotic proteins and tumour cells can acquire a resistance against MOMP through deregulation of B-cell lymphoma 2 family members (Albeck et al. 2008).

Lastly, TRAIL sensitivity is regulated by members of the inhibitor of apoptosis protein (IAP) family, which are characterised by containing at least one baculovirus IAP repeat (BIR) domain (Miller 1999). These proteins are of great appeal for clinical researches worldwide, as they modulate the steps of apoptosis and can be affected by small-molecule compounds (de Almagro \& Vucic 2012). In this regard, cellular IAP1 (cIAP1/BIRC2) and cIAP2 (BIRC3) have been extensively studied and their oncogenic potential refined. Their elevated expression levels have been linked to chemoresistance and poor prognosis in different types of tumours (Kempkensteffen et al. 2007, Miura et al. 2011, Nagata et al. 2011). Both IAPs prevent apoptosis by impeding the activity of caspases 3 and 7 . CIAP1/2 can directly bind caspases via their BIR domain. In addition, they work indirectly through their E3-ligase activity, which allows them to ubiquitinate caspase 3 and 7, labelling them for proteasomal degradation (Choi et al. 2009). This way, they inhibit apoptosis and counteract TRAIL-induced cell death. Interestingly, these two IAPs are antagonized by the second mitochondria-derived activator of caspases (Smac), which is released from the mitochondria upon MOMP (Verhagen et al. 2000).

Over the years, different types of Smac mimetics have been designed with the aim of antagonising cIAP1/2 function and thus sensitising cancer cells to apoptosisinducing stimuli. As a result, Smac mimetics have been successfully implemented in several phase II studies as an integral component of different combinational 
chemotherapy regimes (Bai et al. 2014, Derakhshan et al. 2017). They can be categorised into monovalent and bivalent compounds, depending on the amount of Smac mimicking sequences. Through their proteasomal degradation of CIAP1/2, they clear the way for TRAIL-induced apoptotic signalling and additionally causes the release of RIP-kinase 1 from the tumour necrosis factor receptor 1 (TNFR1), which in turn is incorporated into the DISC, making the cells susceptible for subsequent ensuing programmed cell death (Li 2004, Moulin et al. 2012).

The aim of our study was to evaluate the prognostic and biological role of the TRAIL system in FTC and to elucidate the influence of small-molecule Smac mimetics on TRAIL sensitivity in vitro.

\section{Materials and methods}

\section{Patient selection and clinicopathological data}

For this study, we defined FTC as a malignant lesion of the thyroid gland with follicular differentiation and either capsular or vascular invasion, without papillary nuclear features. As described previously, all patients who underwent surgical resection of their histologically confirmed FTC at the Department of Surgery (A), University Hospital Duesseldorf between 1992 and 2014 were included for primary evaluation (Werner et al. 2017).

Our exclusion criteria included the following features: missing or deficient pathological reports, unavailable clinical or follow-up data, incomplete resection of the cancer and inadequate tumour material for subsequent analyses. Data concerning overall as well as recurrencefree survival and clinical parameters were obtained from our prospectively maintained clinical database. The tumour specimens were staged according to the 7 th edition of the UICC classification (Sobin et al. 2009). The study was carried out in accordance to Good Clinical Practice, the Declaration of Helsinki and local rules as well as regulations of the country. An approval from the institutional ethics committee of the Medical Faculty, Heinrich-Heine-University Duesseldorf was obtained, which functioned as an informed consent statement (reference number: 3821).

\section{Tissue microarray and immunohistochemistry}

All formalin-fixed paraffin-embedded tissue samples were collected from the Institute of Pathology, University Hospital Duesseldorf. For the construction of the tissue microarrays (TMA), two tissue cylinders were taken from the centre of the primary tumour and one from the corresponding non-neoplastic thyroid tissue. Where present, two tissue specimens from lymph node or distant metastases were taken (Werner et al. 2017). All tissue cores had a diameter of $1.0 \mathrm{~mm}$. Immunohistochemical staining was performed according to the ZytoChem Plus HRP-DAB Kit (Zytomed Systems, Berlin, Germany) as described previously (Werner et al. 2016, 2017). For immunohistochemistry, the following primary antibodies were used: mouse monoclonal anti-DR4/TRAIL-R1 (1:50; Adipogen, San Diego, CA, USA), mouse monoclonal anti-DR5/TRAIL-R2 (1:50; Adipogen), mouse monoclonal anti-DcR1/TRAIL-R3 (1:25; Adipogen), rabbit monoclonal anti-DcR2/TRAIL-R4 (1:250; Abcam) and mouse monoclonal anti-TRAIL (1:50; Novus, Littleton, CO, USA).

Isotype control was performed using mouse IgG1k (MOPC-21; 1:50 dilution; Abcam) and rabbit immunoglobulin fraction (Code X0903; 1:1000 dilution; Dako).

For protein expression analyses, two independent reviewers ( $\mathrm{T} \mathrm{A} \mathrm{W,} \mathrm{I} \mathrm{N)} \mathrm{scored} \mathrm{the} \mathrm{staining} \mathrm{intensity} \mathrm{and}$ percentage of stained cells using the immunoreactivity score (I R S) reported by Remmele (Remmele et al. 1986) as described previously (Werner et al. 2016).

The prognostic value of the respective markers was assessed following the reporting recommendations for tumour marker prognostic studies (REMARK) (McShane et al. 2005).

\section{Cell line and cell viability assay}

Human FTC cell line TT2609-C02 (TT) was purchased from the Leibniz Institute DSMZ-German Collection of Microorganisms and Cell Cultures (DSMZ no.: ACC 510). The FTC cell line was cultivated from a secondary RAI refractory FTC and exhibits under culture conditions no significant ${ }^{125}$ I uptake (Geldof et al. 2001). Human FTC cell line FTC133 was acquired from Sigma-Aldrich (catalogue no.: 94060901). It originated from a metastatic FTC and does not exhibit iodine uptake in vitro (Smit et al. 2009).

Cell line authenticity was confirmed by Short Tandem Repeat DNA profiling as described previously (Krieg et al. 2014, Werner et al. 2017). Cell viability was assessed using CellTiter 96 AQueous Non-Radioactive Cell Proliferation Assay (Promega) according to the manufacture's protocol after $72 \mathrm{~h}$ of incubation. Firstly, cells were treated singularly with recombinant human (rh)-TRAIL (SuperKillerTRAIL, Enzo Life Sciences, Lausen, Switzerland) or bivalent Smac mimetic Birinapant or monovalent Smac mimetic 
GDC-0152 (both Selleck Chemicals, Houston, TX, USA) at different concentrations. To evaluate the sensitising effect of the different Smac mimetics on TRAIL-induced apoptosis, cells were co-incubated with different concentrations of rh-TRAIL and the respective Smac mimetic, which was allotted at a concentration of $1 \mu \mathrm{M}$. Effects were stratified according to the fractional product (FP) described by Webb (Webb 1963). First, the measured specific survival rates (sp. survival) of the respective cell lines were calculated after treatment with either rh-TRAIL, Birinapant or GDC-0152 alone or in combination (i.e. sp. survival = viability treatment/viability control). Then, the expected survival rates (e. survival) of a combinational therapy were estimated as the product of the respective measured specific survival rates (i.e. e. survival $=s p$. survival $($ rh-TRAIL $) \times$ sp. survival (Birinapant)). Finally, the FP for the combinational therapy was calculated using the following formula: $\mathrm{FP}=\mathrm{e}$. survival - sp. survival. Values larger than 0.1 were considered a significant sensitising effect.

\section{FACS analysis for apoptosis}

The FITC Annexin V/Dead Cell Apoptosis Kit (Invitrogen by Life Technologies) was used to estimate the impact of the different compounds singularly and in combination on apoptosis. Cells were harvested $72 \mathrm{~h}$ after incubation and then treated according to the manufacturer's protocol. All analyses were conducted using a BD FACSCanto II (BD Biosciences, San Jose, CA, USA).

\section{Western blot analysis}

Cells were harvested after their respective treatment using ice-cold RIPA buffer. Total protein concentrations were measured using a BioPhotometer according to Bradford (Eppendorf, Hamburg, Germany). Proteins were separated using SDS-polyacrylamide gel electrophoresis and transferred onto a nitrocellulose membrane for antibody detection. Membranes were incubated over-night using the following primary antibodies: monoclonal mouse anticIAP1 (1:1000; 5\% NFDM; Novus), monoclonal mouse anti-cIAP2 (1:500; 5\% NFDM; Novus) and monoclonal rabbit anti-GAPDH (1:5000; 5\% NFDM; Cell Signaling).

\section{Statistical analysis}

Overall survival was defined as time in months from the date of surgery until death of any cause or until the last follow-up at which survivors were censored. Univariate survival analyses were performed by log-rank (Mantel Cox) test categorising the respective markers according to the IRS into high ( $\geq$ median) and low expression (<median). Cox regression analyses were employed to estimate hazard ratios (HR) with 95\% confidence intervals (CI) for multivariate analyses. Firstly, the regression analysis was performed considering all available variables and subsequently focused using the stepwise variable selection based on the Akaike information criterion (AIC). Expression levels of the investigated proteins in regard to the clinicopathological parameters were evaluated by the nonparametric Mann-Whitney $U$ test as well as the Fisher's exact test.

In addition, we performed a survival regression tree analysis to identify subgroups of patients with a very high risk of death. This technique combines an algorithm for recursive partitioning together with a well-defined theory of permutation tests. The resulting partitioning is graphically displayed as a classification tree, each node displaying an optimal cut-off point for continuous co-variables.

All statistical analyses were performed using GraphPad Prism (version 6, GraphPad Software) or the Statistical Software R, version 3.1.0 (R Development Core Team, 2014). All cell culture experiments were repeated at least three times. A $P$ value $<0.05$ was considered to indicate statistical significance.

\section{Results}

\section{Expression of TRAIL and its receptors in FTC}

A total of 44 patients were included in this study. The clinicopathological characteristics are summarised in Table 1. Overall, ten of the 44 patients could not be included in the survival analysis due to loss of follow-up. The median overall survival was 47 months (range 0-197 months) with a median follow-up of 62 months (range 0-197 months) based on the reverse Kaplan-Meier procedure. The last follow-up was conducted in December 2015. During the observation period, 9 patients died.

Over the staining process for the different epitopes, 2 tissue discs were lost for TRAIL, 1 tissue disc for TRAIL-R1/DR4, 3 tissue discs for TRAIL-R2/DR5, 3 tissue discs for TRAIL-R3/DcR1 and 3 tissue discs for TRAIL-R4/DcR2. To explore possible associations between the different markers, we compared the IRS across groups for each clinicopathological variable. Interestingly, TRAIL and its receptors TRAIL-R1/DR4, TRAIL-R2/DR5, TRAIL-R3/DcR1 and TRAIL-R4/DcR2 were all significantly higher expressed in FTC tissues when compared to 
Table 1 Patient characteristics $(n=44)$.

\begin{tabular}{lc}
\hline Variables & No. of patients (\%) \\
\cline { 1 - 2 } Total & 44 \\
Age & $59(17-85)$ \\
Median (range) (years) & \\
Gender & $19(43)$ \\
Male & $25(57)$ \\
Female & \\
Type of surgery & $3(7)$ \\
Hemithyroidectomy & $1(2)$ \\
With cervical LND & $11(25)$ \\
Subtotal thyroidectomy & $5(11)$ \\
With cervical LND & $7(16)$ \\
Total thyroidectomy & $17(39)$ \\
With cervical LND & \\
Tumour stage & $24(55)$ \\
T1/2 & $20(45)$ \\
T3/4 & \\
Lymph node metastases & $41(93)$ \\
N0 & $3(7)$ \\
N1a/b & \\
Distant metastases & $38(86)$ \\
M0 & $6(14)$ \\
M1 & \\
UICC stage & $22(50)$ \\
UICC I/II & $22(50)$ \\
UICC III/IV & \\
\hline
\end{tabular}

LND, lymphnode dissection; UICC, Union Internationale Contre le Cancer.

non-neoplastic thyroid tissue samples (TRAIL-R1/DR4: $P<0.001 ; \quad$ TRAIL-R2/DR5: $\quad P<0.001 ; \quad$ TRAIL-R3/DcR1: $P<0.001 ; \quad$ TRAIL-R4/DcR2: $\quad P<0.05$; TRAIL: $\quad P<0.001$; Fig. 1A/B). Additionally, patients with a T3/4 tumour exhibited significantly higher expression levels of TRAIL receptors TRAIL-R2/DR5 and TRAIL-R3/DcR1 and TRAIL-R4/DcR2, when compared to patients with T1/2 tumours (DR5: $P<0.05$; DcR1: $P<0.01$; DcR2: $P<0.05$; Fig. 2A/D and G). Similar results were obtained, when UICC stage III/IV tissue samples were compared with samples of UICC I/II patients. Here, TRAIL-R2/DR5, TRAIL-R3/DcR1 and TRAIL-R4/DcR2 expression levels were associated with advanced tumour stages (TRAIL-R2/DR5: $P<0.05$; TRAIL-R3/DcR1: $\quad P<0.05 ; \quad$ DcR2: $\quad P<0.01 ; \quad$ Fig. $\quad 2 \mathrm{~B} / \mathrm{E}$ and $\mathrm{H})$. Interestingly, we found a strong correlation between TRAIL-R4/DcR2 and TRAIL-R2/DR5 $(r=0.4659$, $P<0.01)$ in the spearman correlation test. In addition, TRAIL-R4/DcR2 expression was also associated with a widely invasive growth pattern, demonstrating significantly higher IRS scores when compared to minimally invasive FTCs $(P<0.05$; Fig. 2I). When comparing primary FTCs with their corresponding lymph node or distant metastases, no differences in expression levels of TRAIL and its receptors became evident (data not shown).
These results were confirmed when we categorised the different IRS scores according to the median into high ( $\geq$ median) and low ( $<$ median) and compared the different groups with the respective clinicopathological parameters using the Fisher's exact test (Supplementary Table 1, see section on supplementary data given at the end of this article).

Next, we correlated the available clinicopathological variables with the overall and recurrence-free survival. In the univariate analysis, high TRAIL-R3/DcR1 expression (HR $=6.041,95 \%$ CI: $1.490-24.50 ; P<0.05)$ as well as high TRAIL-R4/DcR2 expression $(\mathrm{HR}=5.787 ;$ 95\% CI: $1.410-22.99 ; P<0.05)$ was associated with worse prognosis and higher chance of death (Fig. 3A/B and Table 2). This was also the case for widely invasive growing FTCs $(\mathrm{HR}=8.428$, 95\% CI: 1.378-22.30; $P<0.05$; Table 2). Additionally, both TRAIL-R3/DcR1 and TRAIL-R4/DcR2 expression correlated negatively with recurrence-free survival (TRAIL-R3/DcR1:HR=6.314; 95\% CI: 1.628-24.48; $P<0.01$; TRAIL-R4/DcR2: HR=6.404; 95\% CI: 1.393-29.44; $P<0.05$; Fig. 3C/D and Table 2).

The multivariate analysis confirmed the correlation with high TRAIL-R4/DcR2 expression and worse prognosis (HR $=1.459,95 \%$ CI: 1.047-2.034; $P<0.05$ ). In addition, a high age at the time of diagnosis was negatively correlated with overall survival (HR=1.067, 95\% CI: 1.004-1.135; $P<0.05$; Table 3 ). In the subsequent variable, selection procedure based on the AIC age at first diagnosis and high DcR2 expression levels proved to be the most robust markers (age: $\mathrm{HR}=1.080,95 \% \mathrm{CI}: 1.018-1.146 ; P<0.05$; TRAIL-R4/DcR2: $\quad H R=1.427 ， 95 \% \quad$ CI: $1.130-1.803$; $P<0.01$; Table 4). Of note, the AIC decreased during the stepwise variable selection by 10 units, indicating a better goodness of fit of the selection model and suggesting its higher significance (Burnham \& Anderson 2003).

Due to the similarity in events between $\mathrm{T}$ stadium and UICC stage, it was not possible to compute a multivariate analysis with both variables included. Here, we decided on UICC stage because of its broader representation of the tumours stadium, i.e. including $\mathrm{N}$ and $\mathrm{M}$ stage. The computation of a multivariable regression analysis with respect to recurrence-free survival was not contingent due to the small number of events.

\section{Associations between markers}

Because of the diversity of TRAIL receptors, we next tried to elucidate possible interaction between clinicopathological parameters and marker expression levels. Therefore, 
A Primary tumour
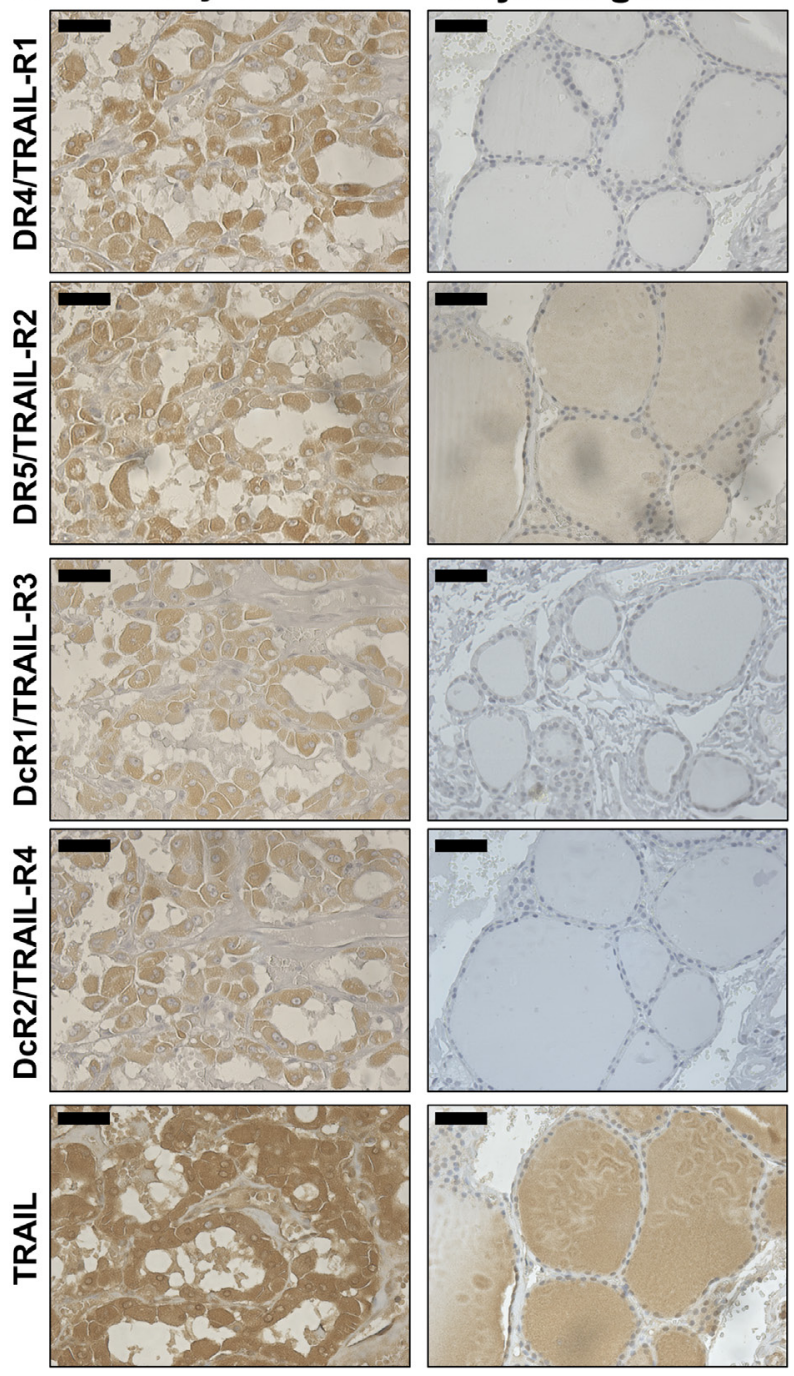

we performed regression tree analyses with continuous co-variables to identify whether a significant association between any of the co-variables and the response variable was given. Interestingly, we found a hierarchical grouping of the two decoy receptors and the clinical variable of age at first diagnosis. Patients with a high TRAIL-R4/DcR2 expression (IRS $>9.5$ ) faced the worst prognosis with three times the risk of dying over the observed period of time (Fig. 3E). The next most powerful deterministic marker in our cohort was the level of TRAIL-R3/DcR1 expression. With the IRS $>3.5$ and the age at diagnosis being $>64.5$ years the patients had a 1.5 times higher chance of death over time.

\section{Rh-TRAIL induces apoptosis in FTC cell line}

FTC cell line TT was susceptible to TRAIL-induced apoptosis. In a dose-dependent manner, rh-TRAIL caused
B
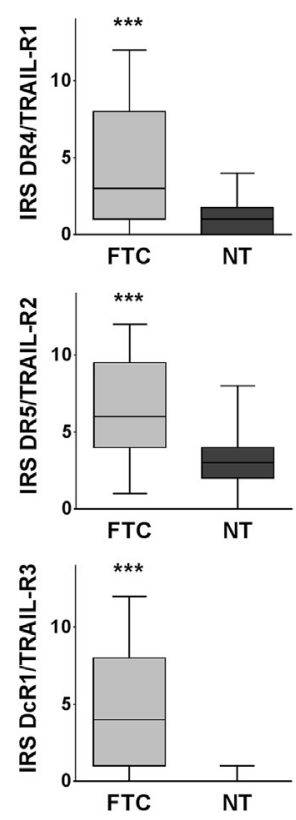

Figure 1

Expression of TRAIL and its receptors in FTC. (A) Representative tissue samples with immunohistochemical staining for TRAIL, TRAIL-R1/DR4, TRAIL-R2/DR5, TRAIL-R3/DcR1 and TRAIL-R4/DCR2 in FTC (left) and normal thyroid gland (right). All shown samples were classified as strong expression for the respective targets in accordance with the IRS. The bar at the top left corner indicates $25 \mu \mathrm{m}$. The pictures were taken at a $400 \times$ magnification. The respective positive and isotype controls are displayed in Supplementary Fig. 1. (B) Expression levels of TRAIL and its receptors in FTC and their association with clinicopathological variables. Boxplots display the median IRS with the upper and lower quartile, as well as maximum and minimum. Statistical significance was calculated by two-tailed nonparametric Mann-Whitney test. FTC, follicular thyroid cancer; NT, non-neoplastic thyroid gland. ${ }^{*} P<0.05 ; * * * P<0.001$.

a decrease in cell viability through the induction of apoptotic cell death, commencing at concentrations as low as $3 \mathrm{ng} / \mathrm{mL}(P<0.01$; Fig. $4 \mathrm{~A})$. The expression levels of the IAPs cIAP1/2 and XIAP remained unchanged (data not shown).

Of note, FTC cell line FTC133 was far less susceptible to TRAIL-induced apoptosis. Here, even at concentrations of $10 \mathrm{ng} / \mathrm{mL}$, no significant decrease in cell viability could be detected (Fig. 4B). These results were corroborated by FITC Annexin staining and FACS, where no significant increase in apoptotic cells could be detected after rh-TRAIL treatment. Again, the protein expression levels of cIAP1/2 as well as XIAP remained unchanged (data not shown).

\section{Smac mimetics facilitate TRAIL sensitivity}

The incubation of the FTC cell lines TT and FTC133 with the Smac mimetics GDC-0152 and Birinapant alone did 

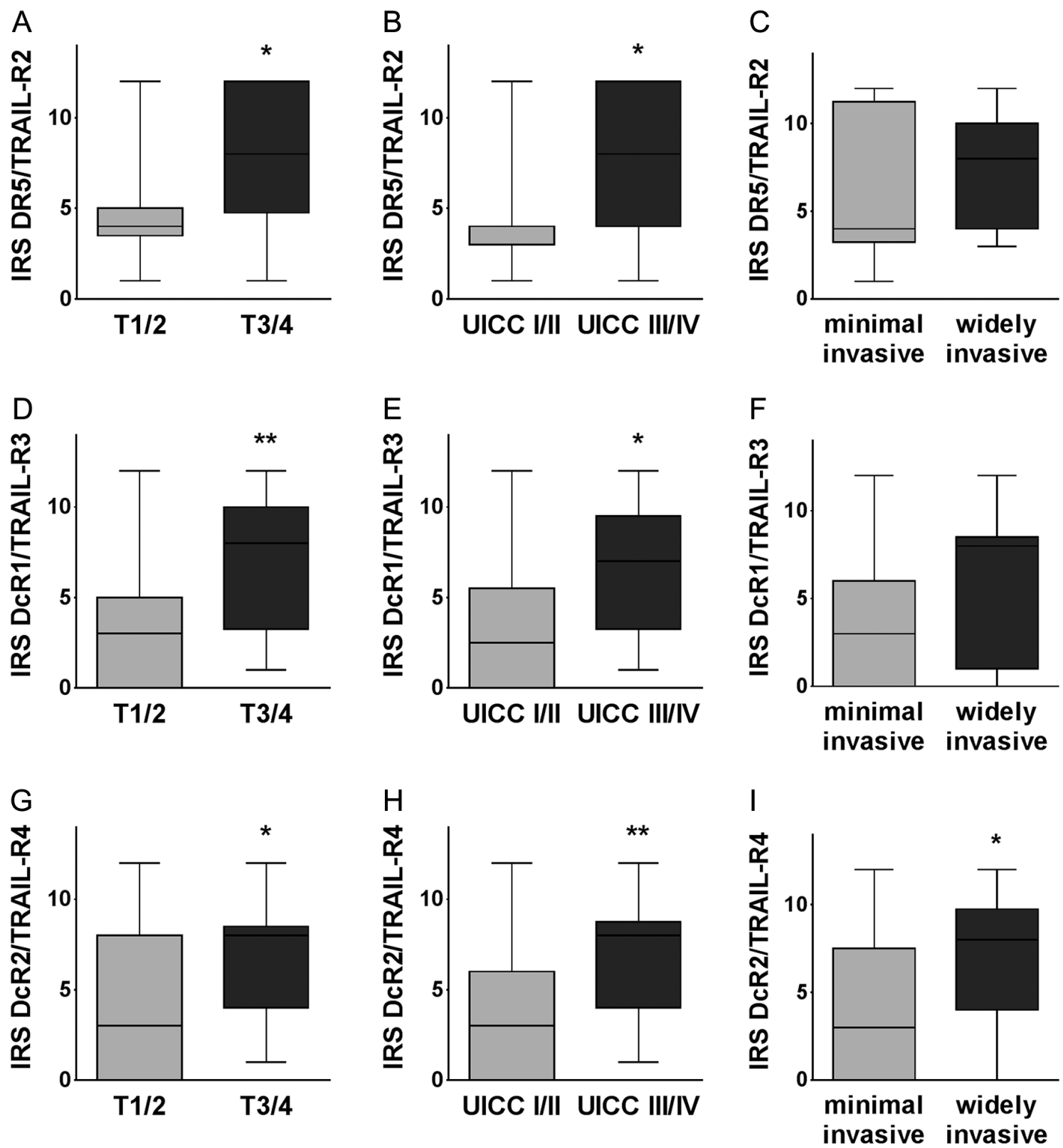

Figure 2

Expression levels of TRAIL-R2/DR5, TRAIL-R3/DCR1 and TRAIL-R4/DCR2 and their association with clinicopathological variables in FTC. (A, B, C, D, E, F, G, H and I) Boxplots display the median IRS with the upper and lower quartile, as well as maximum and minimum grouped according to the respective clinicopathological variable. Statistical significance was calculated by two-tailed nonparametric Mann-Whitney test. *P<0.05; $* * P<0.01$.

not have any impact on cell viability or apoptosis (Fig. 4A, $\mathrm{B}, \mathrm{C}$ and D). To investigate a possible sensitising effect of Smac mimetics on TRAIL-induced apoptosis, we next co-incubated FTC cell lines TT and FTC133 with different concentrations of rh-TRAIL and $1 \mu \mathrm{M}$ GDC-0152 or Birinapant, respectively.

Regarding cell viability, we could demonstrate a significant sensitising effect for both Smac mimetics on FTC cell line TT. Co-incubation of the bivalent Smac mimetic Birinapant and $3 \mathrm{ng} / \mathrm{mL}$ rh-TRAIL caused a reduction of cell viability by $57 \%$, when comparing the expected additive effect with the actual measured results for co-incubation ( $\mathrm{FP}=0.47, P<0.01$; Fig. $4 \mathrm{~A})$. This effect was also present when using the monovalent Smac mimetic GDC-0152. Here, the co-incubation of $3 \mathrm{ng} / \mathrm{mL}$ rh-TRAIL with $1 \mu \mathrm{M}$ GDC-0152 caused a reduction in cell viability by $45 \%(\mathrm{FP}=0.3, P<0.01$; Fig. $4 \mathrm{C})$. In the thyroid cancer cell line, FTC133 on the other hand, only bivalent 
A
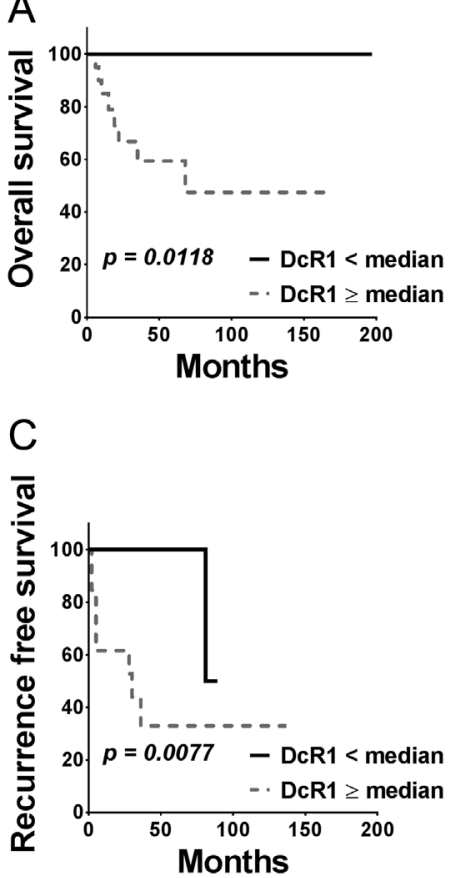

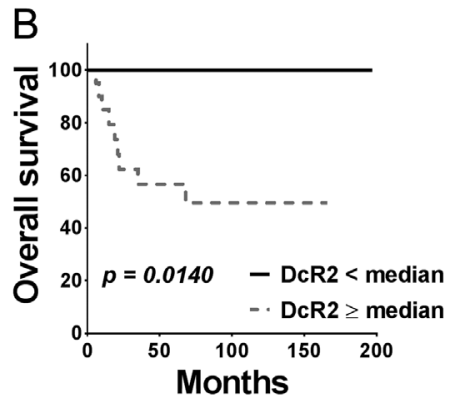

$\mathrm{E}$
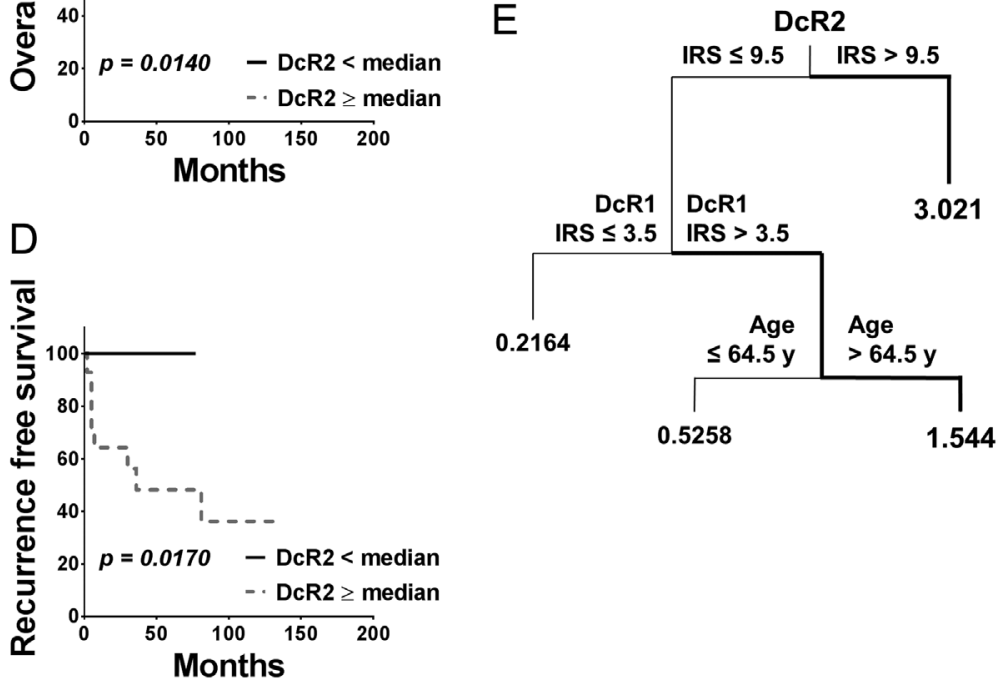

Figure 3

TRAIL-R3/DCR1 and TRAIL-R4/DCR2 are negatively associated with overall and recurrence-free survival. Kaplan-Meier curves illustrate the relationship between expression of TRAIL-R3/DCR1 (A/C) or TRAIL-R4/DCR2 (B/D) and overall as well as recurrence-free survival. Based on the IRS of TRAIL-R3/DCR1 or TRAIL-R4/DCR2, specimens were classified into samples with high ( $\geq$ median) and low ( $<$ median) expression levels. (E) Survival regression tree analyses were performed to identify marker constellation with a high risk of death. Numbers under the vertical lines represent HRs of the given constellation.

Smac mimetic Birinapant was capable of sensitising the primary resistant cell line to TRAIL-induced apoptosis. While rh-TRAIL alone was not capable of reducing cell viability, the co-incubation of $3 \mathrm{ng} / \mathrm{mL}$ rh-TRAIL with $1 \mu \mathrm{M}$ Birinapant resulted in a significant decrease in cell viability of an additional $26 \%$ ( $F P=0.17, P<0.01$; Fig. $4 \mathrm{~B}$ ). This effect was however not present for the co-incubation of FTC133 with rh-TRAIL and monovalent Smac mimetic GDC-0152 (Fig. 4D).

The sensitising impact on cell viability is caused by an increase in apoptotic cells. The co-incubation of $0.3 \mathrm{ng} / \mathrm{mL}$ rh-TRAIL with $1 \mu \mathrm{M}$ Birinapant caused a doubling in the apoptotic cell count for FTC cell line TT, when compared to treatment with rh-TRAIL alone $(P<0.05$; Fig. 4A). Similarly, in FTC133 the co-incubation of $1 \mathrm{ng} / \mathrm{mL}$ rh-TRAIL with $1 \mu \mathrm{M}$ Birinapant resulted in tripling the amount of apoptotic cells $(P<0.05$; Fig. $4 \mathrm{~B})$.

The co-incubation of FTC cell line TT with $0.3 \mathrm{ng} / \mathrm{mL}$ rh-TRAIL and $1 \mu \mathrm{M}$ GDC-0152 resulted in more than 2.6 times the amount of apoptotic cells when compared to incubation with rh-TRAIL alone $(P<0.05$; Fig. 4 C). This ratio remained apparent throughout the higher rh-TRAIL concentrations. This sensitising effect was, however, not observed in thyroid cancer cell line FTC133 (Fig. 4D).

\section{CIAP1/2 degradation induces TRAIL sensitivity}

To further elucidate the possible mechanisms behind the sensitising effect of the Smac mimetics GDC-0152 and Birinapant, we next investigated the expression levels of their target proteins cIAP1/2. FTC cell lines TT and FTC133 were treated with different concentrations of the respective compounds and subsequent Western blot

Table 2 Univariate survival analysis.

\begin{tabular}{|c|c|c|c|}
\hline Variables & HR & Cl (lower-upper 95\%) & P-Value \\
\hline Age at first diagnosis & 2.225 & $0.644-7.694$ & 0.206 \\
\hline Sex & 0.485 & $0.130-1.808$ & 0.281 \\
\hline T1/2 vs T3/4 & 3.038 & $0.820-11.250$ & 0.096 \\
\hline UICC I/II vs UICC III/IV & 2.503 & $0.67-9.358$ & 0.173 \\
\hline $\begin{array}{l}\text { Minimally vs widely } \\
\text { invasive }\end{array}$ & 8.428 & $1.378-22.300$ & 0.016 \\
\hline $\begin{array}{l}\text { TRAIL-R1/DR4 } \\
\text { expression }\end{array}$ & 3.099 & $0.731-13.130$ & 0.215 \\
\hline $\begin{array}{l}\text { TRAIL-R2/DR5 } \\
\text { expression }\end{array}$ & 3.882 & $0.626-24.090$ & 0.145 \\
\hline $\begin{array}{l}\text { TRAIL-R3/DcR1 } \\
\text { expression }\end{array}$ & 6.041 & $1.490-24.500$ & 0.012 \\
\hline $\begin{array}{l}\text { TRAIL-R4/DcR2 } \\
\text { expression }\end{array}$ & 5.787 & $1.410-22.990$ & 0.016 \\
\hline TRAIL expression & 0.401 & $0.088-1.817$ & 0.236 \\
\hline
\end{tabular}

(c) 2018 Society for Endocrinology Published by Bioscientifica Ltd. Printed in Great Britain 
Table 3 Multivariate survival analysis $(\mathrm{AIC}=60)$.

\begin{tabular}{|c|c|c|c|}
\hline Variables & HR & CI (lower-upper 95\%) & P-Value \\
\hline Age at first diagnosis & 1.067 & $1.004-1.135$ & 0.038 \\
\hline Sex & 0.578 & $0.080-4.199$ & 0.588 \\
\hline UICC I/II vs UICC III/IV & 0.496 & $0.039-6.329$ & 0.590 \\
\hline $\begin{array}{l}\text { Minimally vs widely } \\
\text { invasive }\end{array}$ & 4.166 & $0.313-55.403$ & 0.280 \\
\hline $\begin{array}{l}\text { TRAIL-R1/DR4 } \\
\text { expression }\end{array}$ & 0.966 & $0.725-1.288$ & 0.814 \\
\hline $\begin{array}{l}\text { TRAIL-R2/DR5 } \\
\text { expression }\end{array}$ & 0.939 & $0.630-1.401$ & 0.760 \\
\hline $\begin{array}{l}\text { TRAIL-R3/DcR1 } \\
\text { expression }\end{array}$ & 1.108 & $0.842-1.458$ & 0.464 \\
\hline $\begin{array}{l}\text { TRAIL-R4/DcR2 } \\
\text { expression }\end{array}$ & 1.459 & $1.047-2.034$ & 0.026 \\
\hline TRAIL expression & 0.872 & $0.573-1.328$ & 0.525 \\
\hline
\end{tabular}

analyses were performed. The bivalent Smac mimetic Birinapant demonstrated in both cell lines, a marked reduction of both cIAP1 and cIAP2, with an apparent higher impact on cIAP1 (Fig. 4A/B). Monovalent Smac mimetic GDC-0152 on the other hand demonstrated a distinct reduction of cIAP1 in both FTC cell lines, while the effect in FTC133 was less profound in the lower concentrations. However, in FTC133 cells, a degradation of cIPA2 through incubation with GDC-0152 was not observable (Fig. 4C/D).

\section{Discussion}

FTC is one of the most common endocrine malignancies in men. Its predominantly beneficial course is mainly dependent on postoperative RAI treatment. However, once the tumour fails to adequately retain RAI the 10-year disease-specific survival rate deteriorates to below $10 \%$ (Durante et al. 2006, Vaisman et al. 2015). Considerable efforts in this field of research have led to an expanding arsenal of tyrosine kinase inhibitors (TKI) at the oncologist's disposal. The most likely outcome however is stable disease, with no potential for a cure (Gruber \& Colevas 2015). Because TKIs involve life-long treatments, the worry of protracted toxicity and subsequent detriment

Table 4 Multivariate survival analysis after stepwise variable selection $(\mathrm{AIC}=49)$.

\begin{tabular}{|c|c|c|c|}
\hline Variables & HR & Cl (lower-upper 95\%) & P-Value \\
\hline Age at first diagnosis & 1.080 & $1.018-1.146$ & 0.011 \\
\hline TRAIL-R4/DcR2 expression & 1.427 & $1.130-1.803$ & 0.003 \\
\hline
\end{tabular}

AIC, Akaike information criterion; Cl, confidence interval; DCR1/2, decoy receptor 1/2; DR4/5, death receptor 4/5; HR, hazard ratio; TRAIL, TNF-related apoptosis-inducing ligand; UICC, Union Internationale Contre le Cancer. in quality of life is imminent (Brose et al. 2014, Gruber \& Colevas 2015).

In this regard offers the TRAIL system an appealing advantage. Its capacity to selectively induce apoptosis in cancer cells offers the potential of cure by little to no side effects. However, multiple cancers demonstrate an intrinsic resistance against TRAIL-induced apoptosis (Todaro et al. 2008). Thus far, little is known about the role of TRAIL and its receptors in FTC and its possible resistant mechanisms. To our knowledge, this is the first study, which focused on the stage-dependent expression of TRAIL and its receptors in FTC and investigated not only its prognostic relevance but also possible resistant mechanisms.

TRAIL and its receptors all demonstrated a significantly higher expression in cancer tissue when compared to its corresponding non-neoplastic thyroid tissue. Notably however, only the decoy receptors TRAIL-R3/DcR1 and TRAIL-R4/DcR2 as well as TRAIL-R2/DR5 demonstrated a stage-dependent expression pattern. Furthermore, only TRAIL-R4/DcR2 proved to be independent negative prognostic marker, while the regression tree analysis offered a hierarchical structure with TRAIL-R4/DcR2 at the top, followed by TRAIL-R3/DcR1 as the second most important marker. Despite the regression tree being a solely exploratory statistical method, it still underscores the complex interdependency of the different receptor types and the relevance of their differentiated expression for patients' outcome.

In addition, we could show that an advanced age at the time of first diagnosis proved to be an independent negative prognostic marker. This finding has been reported previously by other groups and is included in the FTC staging system (Cooper et al. 2009). But since the age at diagnosis has been on the rise over the last decades (Song et al. 2017), it underscores the relevance of early detection strategies in FTC.

TRAIL holds the widest variety of receptors within the TNF family. With two of the four membrane-bound receptors being regulatory, the importance of a finely tuned balance between TRAIL activation and inhibition is eminent. The decoy receptors compete with the DD-containing receptors for ligand binding, thus reducing TRAIL effectiveness (Lemke et al. 2014). Both decoy receptors haven been shown to inhibit TRAIL-mediated apoptosis when overexpressed in a cell autonomous manner (Mérino et al. 2006, Morizot et al. 2011) and by influencing the tumour microenvironment ( $\mathrm{O}^{\prime}$ Leary et al. 2016). Indeed, they have been linked with poor prognosis in different malignancies (Riccioni et al. 2005, Ganten et al. 2009). 

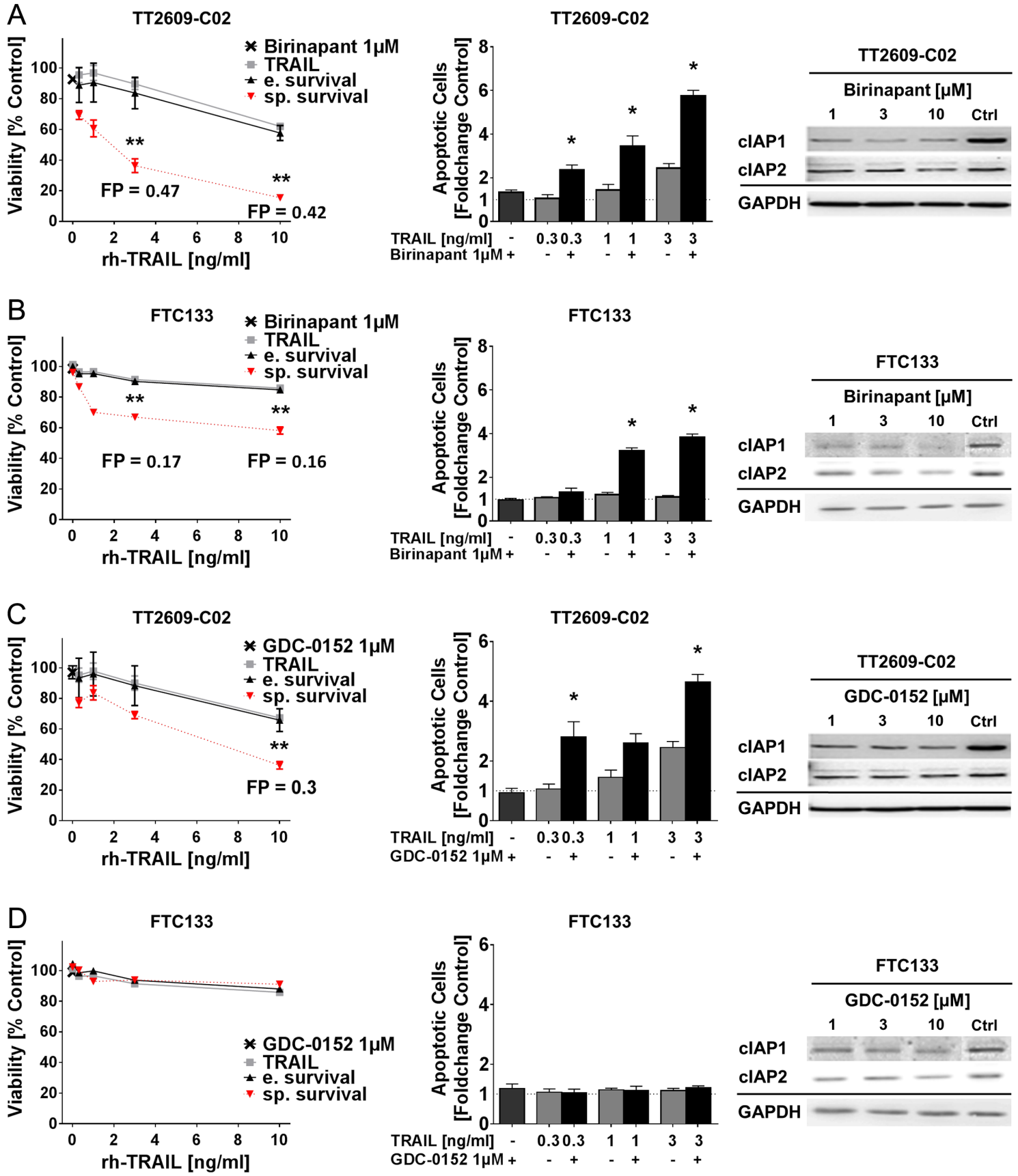

Figure 4

Birinapant and GDC-0152 sensitise FTC cell lines for TRAIL-induced apoptosis. FTC cell lines were treated with increasing concentrations of rh-TRAIL with and without Smac mimetics Birinapant (A/B) and GDC-0152 (C/D). Changes in cell viability are illustrated linearly in percentage control and stratified according to the FP. While FTC cell line TT2609-C02 was susceptible to rh-TRAIL alone (A/C), cell line FTC133 proved to be resistant to rh-TRAIL-induced apoptosis (B/D). Smac mimetic treatment alone had no impact on cell viability (A, B, C and D). Annexin V/PI staining and FACS analyses of FTC cells demonstrate the changes of annexin positive apoptotic cells after incubation with rh-TRAIL alone (-) or in combination (+) with Smac mimetics Birinapant (A/B) or GDC-0152 (C/D). Changes in protein expression of cIAP1/2 after treatment with the respective Smac mimetic are illustrated using Western blot. GAPDH served as loading control. Blots are cropped to increase clarity. Statistical significance was calculated by two-tailed nonparametric Mann-Whitney test. (E) Survival, expected survival; sp. survival, specific survival; FP, fractional product; ${ }^{*} P<0.05 ;{ }^{*} P<0.01$.

TRAIL-R2/DR5 on the other hand does not only harbour a DD but can also provoke pro-survival pathways by activating NF-kB and MAPK signalling
(Azijli et al. 2013), causing enhanced migration and invasiveness in TRAIL-resistant cancers (Ishimura et al. 2006, Trauzold et al. 2006). Hence, it is not uncommon http://erc.endocrinology-journals.org https://doi.org/10.1530/ERC-17-0479 (c) 2018 Society for Endocrinology Published by Bioscientifica Ltd. Printed in Great Britain 
for tumours to retain their DD-containing receptors throughout oncogenesis, suggesting a survival advantage once the non-cell death signalling pathways take over (Lemke et al. 2014).

The hallmark feature of oncogenesis and subsequent chemoresistance is to evade apoptosis. This is mainly attributed to the upregulation of anti-apoptotic genes like the IAP family members (Zhang et al. 2004, Tirrò et al. 2006, Fulda 2014, Obexer \& Ausserlechner 2014). While cIAP1/2 are capable of directly binding caspases-3 and -7 , they are not capable of inhibiting them through their binding (Eckelman \& Salvesen 2006). They rather ubiquitinate the caspases, thus labelling them for proteasomal degradation (Choi et al. 2009). Additionally, through ubiquitination of RIP1, cIAP1/2 prevents its recruitment to the FADD-associated cell death-activating complex, furthering its anti-apoptotic potential (Ofengeim \& Yuan 2013).

Both FTC cell lines used in this study originated from metastatic FTC and demonstrate no relevant iodine uptake under culture conditions (Geldof et al. 2001, Smit et al. 2009). In addition, while FTC cell line TT was highly sensitive to rh-TRAIL treatment alone, cell line FTC133 proved to be resistant to TRAIL-induced apoptosis, thus posing an excellent model for our study. Interestingly, both Smac mimetics alone were not capable of inducing programmed cell death. This unresponsiveness to Smac mimetics is quite a common feat of cancer cell lines (Petersen et al. 2007). It is mainly attributed to the TNFA mediated upregulation of cIAP2 via NF-kB (Petersen et al. 2010), which counteracts the release of RIPK1 from the TNFR1 and subsequent activation of the FADD-associated cell death-activating complex (Bai et al. 2014).

Here, we could demonstrate that the co-incubation of rh-TRAIL with Smac mimetics not only causes an over-additive effect on TRAIL-induced apoptosis, but can also overcome TRAIL resistance. In the already TRAILsensitive FTC cell line TT the co-incubation with both Smac mimetics resulted in a significant decrease in cell viability through a significant increase in apoptotic cells, caused by a marked degradation of both cIAP1 and cIAP2. The primary unresponsive cell line FTC133 on the other hand became sensitised to rh-TRAIL treatment only through co-incubation with the bivalent Smac mimetic Birinapant. The monovalent compound GDC-0152 was not able to overcome the cell inherent TRAIL resistance. In contrast to GDC-0152, Birinapant induced a marked decrease in both cIAP1/2 protein expressions in FTC133, which was not apparent after GDC-0152 treatment. This difference may be explained by their varying inhibitory capacity towards cIAP1/2. Whereas GDC-0152 contains only one mimicking sequence, the bivalent Smac mimetic Birinapant features two of these sequences. This results in Birinapant's higher affinity to cIAP1/2 and subsequently lower concentration at which $50 \%$ of the IAP's activity is inhibited (Derakhshan et al. 2017). Our findings suggest that highly effective Smac mimetics are needed to overcome TRAIL resistance, whereas less potent mimetics are sufficient to sensitise only already TRAIL susceptible cell lines (Bai et al. 2014).

Targeted therapy is the cornerstone of individualised chemotherapy. The combination of different therapeutic agents like small-molecule mimetics with other chemotherapeutics enables oncologists to complement the effectiveness of their treatment regimes and tailor it to their patients' needs. However, only with the knowledge of the tumour's biology and initial or acquired resistance mechanisms is the development of new therapeutic strategies possible. Our results underscore the prominent role of IAPs and their adversaries in the TRAIL-dependent signalling pathways. We provide first evidence of the importance of the TRAIL system in FTC and IAP-dependent resistance mechanisms. This might prove a promising approach to overcome TRAIL resistance and offer patients with RAI refractory disease a new therapeutic option in the future.

\section{Supplementary data}

This is linked to the online version of the paper at https://doi.org/10.1530/ ERC-17-0479.

\section{Declaration of interest}

The authors declare that there is no conflict of interest that could be perceived as prejudicing the impartiality of the research reported.

\section{Funding}

The study was supported, in part, by a grant from the Deutsche Forschungsgemeinschaft (KR 3496/2-1 to A K), the Forschungskommission of the Medical Faculty, University Duesseldorf (39/2014 to A K and T A W) and by the Duesseldorf School of Oncology (D01.3.1hei-ps to I N, funded by the Comprehensive Cancer Center Duesseldorf/Deutsche Krebshilfe and the Medical Faculty HHU Duesseldorf).

\section{Author contribution statement}

T A W, I N, L D, K R, J C R, S C S and M S performed the experiments. $\mathrm{T} A \mathrm{~W}$ and $\mathrm{A} K$ wrote the manuscript. P E V performed statistical analyses. $A K$ and $T A$ A designed the study. A K and $W T K$ directed the study. All authors reviewed the manuscript. 


\section{References}

Albeck JG, Burke JM, Aldridge BB, Zhang M, Lauffenburger DA \& Sorger PK 2008 Quantitative analysis of pathways controlling extrinsic apoptosis in single cells. Molecular Cell 30 11-25. (https:// doi.org/10.1016/j.molcel.2008.02.012)

Anderson RT, Linnehan JE, Tongbram V, Keating K \& Wirth LJ 2013 Clinical, safety, and economic evidence in radioactive iodinerefractory differentiated thyroid cancer: a systematic literature review. Thyroid 23 392-407. (https://doi.org/10.1089/thy.2012.0520)

Azijli K, Weyhenmeyer B, Peters GJ, de Jong S \& Kruyt FAE 2013 Noncanonical kinase signaling by the death ligand TRAIL in cancer cells: discord in the death receptor family. Cell Death and Differentiation 20 858-868. (https://doi.org/10.1038/cdd.2013.28)

Bai L, Smith DC \& Wang S 2014 Small-molecule SMAC mimetics as new cancer therapeutics. Pharmacology and Therapeutics 144 82-95. (https://doi.org/10.1016/j.pharmthera.2014.05.007)

Bonavida B, Ng CP, Jazirehi A, Schiller G \& Mizutani Y 1999 Selectivity of TRAIL-mediated apoptosis of cancer cells and synergy with drugs: the trail to non-toxic cancer therapeutics (review). International Journal of Oncology 15 793-802. (https://doi.org/10.3892/ijo.15.4.793)

Brose MS, Nutting CM, Jarzab B, Elisei R, Siena S, Bastholt L, la Fouchardiere de C, Pacini F, Paschke R, Shong YK, et al. 2014 Sorafenib in radioactive iodine-refractory, locally advanced or metastatic differentiated thyroid cancer: a randomised, double-blind, phase 3 trial. Lancet 384 319-328. (https://doi.org/10.1016/S01406736(14)60421-9)

Burnham KP \& Anderson DR 2003 Model Selection and Multimodel Inference. New York, NY, USA: Springer Science \& Business Media.

Byrd JK, Yawn RJ, Wilhoit CST, Sora ND, Meyers L, Fernandes J \& Day T 2012 Well differentiated thyroid carcinoma: current treatment. Current Treatment Options in Oncology 13 47-57. (https://doi. org/10.1007/s11864-011-0173-1)

Choi YE, Butterworth M, Malladi S, Duckett CS, Cohen GM \& Bratton SB 2009 The E3 ubiquitin ligase cIAP1 binds and ubiquitinates caspase- 3 and -7 via unique mechanisms at distinct steps in their processing. Journal of Biological Chemistry $\mathbf{2 8 4}$ 12772-12782. (https://doi.org/10.1074/jbc.M807550200)

Cooper DS, Doherty GM, Haugen BR, Kloos RT, Lee SL, Mandel SJ, Mazzaferri EL, McIver B, Pacini F, Schlumberger M, et al. 2009 Revised American Thyroid Association Management Guidelines for patients with thyroid nodules and differentiated thyroid cancer. Thyroid 19 1167-1214. (https://doi.org/10.1089/thy.2009.0110)

de Almagro MC \& Vucic D 2012 The inhibitor of apoptosis (IAP) proteins are critical regulators of signaling pathways and targets for anti-cancer therapy. Experimental Oncology 34 200-211.

Degli-Esposti MA, Dougall WC, Smolak PJ, Waugh JY, Smith CA \& Goodwin RG 1997 The novel receptor TRAIL-R4 induces NF-кB and protects against TRAIL-mediated apoptosis, yet retains an incomplete death domain. Immunity 7 813-820. (https://doi.org/10.1016/S10747613(00)80399-4)

Derakhshan A, Chen Z \& Van Waes C 2017 Therapeutic small molecules target inhibitor of apoptosis proteins in cancers with deregulation of extrinsic and intrinsic cell death pathways. Clinical Cancer Research 23 1379-1387. (https://doi.org/10.1158/1078-0432.CCR-16-2172)

Dralle H, Musholt TJ, Schabram J, Steinmüller T, Frilling A, Simon D, Goretzki PE, Niederle B, Scheuba C, Clerici T, et al. 2013 German association of endocrine surgeons practice guideline for the surgical management of malignant thyroid tumors. Langenbecks Archiv Für Klinische Chirurgie 398 347-375. (https://doi.org/10.1007/s00423013-1057-6)

Durante C, Haddy N, Baudin E, Leboulleux S, Hartl D, Travagli JP, Caillou B, Ricard M, Lumbroso JD, De Vathaire F, et al. 2006 Longterm outcome of 444 patients with distant metastases from papillary and follicular thyroid carcinoma: benefits and limits of radioiodine therapy. Journal of Clinical Endocrinology and Metabolism 91 2892-2899. (https://doi.org/10.1210/jc.2005-2838)

Eckelman BP \& Salvesen GS 2006 The human anti-apoptotic proteins cIAP1 and cIAP2 bind but do not inhibit caspases. Journal of Biological Chemistry 281 3254-3260. (https://doi.org/10.1074/jbc. M510863200)

Eustatia-Rutten CFA, Corssmit EPM, Biermasz NR, Pereira AM, Romijn JA \& Smit JW 2006 Survival and death causes in differentiated thyroid carcinoma. Journal of Clinical Endocrinology and Metabolism 91 313-319. (https://doi.org/10.1210/jc.2005-1322)

Fulda S 2014 Molecular pathways: targeting inhibitor of apoptosis proteins in cancer - from molecular mechanism to therapeutic application. Clinical Cancer Research 20 289-295. (https://doi. org/10.1158/1078-0432.CCR-13-0227)

Ganten TM, Haas TL, Sykora J, Stahl H, Sprick MR, Fas SC, Krueger A, Weigand MA, Grosse-Wilde A, Stremmel W, et al. 2004 Enhanced caspase-8 recruitment to and activation at the DISC is critical for sensitisation of human hepatocellular carcinoma cells to TRAILinduced apoptosis by chemotherapeutic drugs. Cell Death and Differentiation 11 (Supplement 1) S86-S96. (https://doi.org/10.1038/ sj.cdd.4401437)

Ganten TM, Sykora J, Koschny R, Batke E, Aulmann S, Mansmann U, Stremmel W, Sinn H-P \& Walczak H 2009 Prognostic significance of tumour necrosis factor-related apoptosis-inducing ligand (TRAIL) receptor expression in patients with breast cancer. Journal of Molecular Medicine 87 995-1007. (https://doi.org/10.1007/s00109009-0510-z)

Geldof AA, Versteegh LRT, van Mourik JC, Rooimans MA, Arwert F, Hermsen MA, Schadee-Eestermans IL, van Dongen GA, van der Valk P, van der Clement EHP, et al. 2001 Clonally related but phenotypically divergent human cancer cell lines derived from a single follicular thyroid cancer recurrence (TT2609). Thyroid 11 909-917. (https://doi.org/10.1089/105072501753210966)

Griffith TS \& Lynch DH 1998 TRAIL: a molecule with multiple receptors and control mechanisms. Current Opinion in Immunology 10 559-563.

Gruber JJ \& Colevas AD 2015 Differentiated thyroid cancer: focus on emerging treatments for radioactive iodine-refractory patients. Oncologist 20 113-126. (https://doi.org/10.1634/ theoncologist.2014-0313)

Hundahl SA, Cady B, Cunningham MP, Mazzaferri E, McKee RF, Rosai J, Shah JP, Fremgen AM, Stewart AK \& Hölzer S 2000 Initial results from a prospective cohort study of 5583 cases of thyroid carcinoma treated in the United States during 1996. Cancer 89 202-217. (https://doi.org/10.1002/1097-0142(20000701)89:1<202::AIDCNCR27>3.0.CO;2-A)

Ishimura N, Isomoto H, Bronk SF \& Gores GJ 2006 Trail induces cell migration and invasion in apoptosis-resistant cholangiocarcinoma cells. American Journal of Physiology: Gastrointestinal and Liver Physiology 290 G129-G136. (https://doi.org/10.1152/ ajpgi.00242.2005)

Kempkensteffen C, Hinz S, Christoph F, Köllermann J, Krause H, Schrader M, Schostak M, Miller K \& Weikert S 2007 Expression parameters of the inhibitors of apoptosis cIAP1 and cIAP2 in renal cell carcinomas and their prognostic relevance. International Journal of Cancer 120 1081-1086. (https://doi.org/10.1002/ijc.22416)

Kischkel FC, Lawrence DA, Chuntharapai A, Schow P, Kim KJ \& Ashkenazi A 2000 Apo2L/TRAIL-dependent recruitment of endogenous FADD and caspase- 8 to death receptors 4 and 5 . Immunity 12 611-620. (https://doi.org/10.1016/S10747613(00)80212-5)

Kischkel FC, Lawrence DA, Tinel A, LeBlanc H, Virmani A, Schow P, Gazdar A, Blenis J, Arnott D \& Ashkenazi A 2001 Death receptor recruitment of endogenous caspase-10 and apoptosis initiation in the absence of caspase-8. Journal of Biological Chemistry 276 46639-46646. (https://doi.org/10.1074/jbc.M105102200)
(2) 2018 Society for Endocrinology Published by Bioscientifica Ltd. Printed in Great Britain 
Krieg A, Mersch S, Boeck I, Dizdar L, Weihe E, Hilal Z, Krausch M, Möhlendick B, Topp SA, Piekorz RP, et al. 2014 New model for gastroenteropancreatic large-cell neuroendocrine carcinoma: establishment of two clinically relevant cell lines. PLOS ONE 9 e88713. (https://doi.org/10.1371/journal.pone.0088713)

Lemke J, Karstedt von S, Zinngrebe J \& Walczak H 2014 Getting TRAIL back on track for cancer therapy. Cell Death and Differentiation 21 1350-1364. (https://doi.org/10.1038/cdd.2014.81)

Li L 2004 A small molecule smac mimic potentiates TRAIL- and TNFmediated cell death. Science 305 1471-1474. (https://doi. org/10.1126/science.1098231)

Martin S, Maurice T, Vathaire FD, Catherine H, Gardet P, Travagli J-P, Fragu P, Lumbroso J, Caillou B \& Parmentier C 2013 Long-term results of treatment of 283 patients with lung and bone metastases from differentiated thyroid carcinoma. Journal of Clinical Endocrinology and Metabolism 63 960-967. (https://doi.org/10.1210/ jcem-63-4-960)

McShane LM, Altman DG, Sauerbrei W, Taube SE, Gion M, Clark GM \& Statistics Subcommittee of the NCI-EORTC Working Group on Cancer Diagnostics 2005 Reporting recommendations for tumor marker prognostic studies (REMARK). Journal of the National Cancer Institute 97 1180-1184. (https://doi.org/10.1093/jnci/dji237)

Mérino D, Lalaoui N, Morizot A, Schneider P, Solary E \& Micheau O 2006 Differential inhibition of TRAIL-mediated DR5-DISC formation by decoy receptors 1 and 2. Molecular and Cellular Biology 26 7046-7055. (https://doi.org/10.1128/MCB.00520-06)

Miller LK 1999 An exegesis of IAPs: salvation and surprises from BIR motifs. Trends in Cell Biology 9 323-328. (https://doi.org/10.1016/ s0962-8924(99)01609-8)

Miura K, Fujibuchi W, Ishida K, Naitoh T, Ogawa H, Ando T, Yazaki N, Watanabe K, Haneda S, Shibata C, et al. 2011 Inhibitor of apoptosis protein family as diagnostic markers and therapeutic targets of colorectal cancer. Surgery Today 41 175-182. (https://doi.org/10.1007/ s00595-010-4390-1)

Morizot A, Merino D, Lalaoui N, Jacquemin G, Granci V, Iessi E, Lanneau D, Bouyer F, Solary E, Chauffert B, et al. 2011 Chemotherapy overcomes TRAIL-R4-mediated TRAIL resistance at the DISC level. Cell Death and Differentiation 18 700-711. (https:// doi.org/10.1038/cdd.2010.144)

Moulin M, Anderton H, Voss AK, Thomas T, Wong WW-L, Bankovacki A, Feltham R, Chau D, Cook WD, Silke J, et al. 2012 IAPs limit activation of RIP kinases by TNF receptor 1 during development. EMBO Journal 31 1679-1691. (https://doi.org/10.1038/ emboj.2012.18)

Nagane M, Huang HJ \& Cavenee WK 2001 The potential of TRAIL for cancer chemotherapy. Apoptosis 6 191-197. (https://doi. org/10.1023/A:1011336726649)

Nagata M, Nakayama H, Tanaka T, Yoshida R, Yoshitake Y, Fukuma D, Kawahara K, Nakagawa Y, Ota K, Hiraki A, et al. 2011 Overexpression of cIAP2 contributes to 5-FU resistance and a poor prognosis in oral squamous cell carcinoma. British Journal of Cancer 105 1322-1330. (https://doi.org/10.1038/bjc.2011.387)

O'Leary L, van der Sloot AM, Reis CR, Deegan S, Ryan AE, Dhami SPS, Murillo LS, Cool RH, Correa de Sampaio P, Thompson K, et al. 2016 Decoy receptors block TRAIL sensitivity at a supracellular level: the role of stromal cells in controlling tumour TRAIL sensitivity. Oncogene 35 1261-1270. (https://doi.org/10.1038/ onc.2015.180)

Obexer P \& Ausserlechner MJ 2014 X-linked inhibitor of apoptosis protein - a critical death resistance regulator and therapeutic target for personalized cancer therapy. Frontiers in Oncology 4 197. (https:// doi.org/10.3389/fonc.2014.00197)

Ofengeim D \& Yuan J 2013 Regulation of RIP1 kinase signalling at the crossroads of inflammation and cell death. Nature Reviews: Molecular Cell Biology 14 727-736. (https://doi.org/10.1038/nrm3683)
Pan G 1997 An antagonist decoy receptor and a death domaincontaining receptor for TRAIL. Science 277 815-818. (https://doi. org/10.1126/science.277.5327.815)

Petersen SL, Wang L, Yalcin-Chin A, Li L, Peyton M, Minna J, Harran P \& Wang X 2007 Autocrine TNF $\alpha$ signaling renders human cancer cells susceptible to smac-mimetic-induced apoptosis. Cancer Cell 12 445-456. (https://doi.org/10.1016/j.ccr.2007.08.029)

Petersen SL, Peyton M, Minna JD \& Wang X 2010 Overcoming cancer cell resistance to Smac mimetic induced apoptosis by modulating cIAP-2 expression. PNAS 107 11936-11941. (https://doi.org/10.1073/ pnas.1005667107)

Remmele W, Hildebrand U, Hienz HA, Klein PJ, Vierbuchen M, Behnken LJ, Heicke B \& Scheidt E 1986 Comparative histological, histochemical, immunohistochemical and biochemical studies on oestrogen receptors, lectin receptors, and Barr bodies in human breast cancer. Virchows Archiv 409 127-147. (https://doi.org/10.1007/ bf00708323)

Riccioni R, Pasquini L, Mariani G, Saulle E, Rossini A, Diverio D, Pelosi E, Vitale A, Chierichini A, Cedrone M, et al. 2005 TRAIL decoy receptors mediate resistance of acute myeloid leukemia cells to TRAIL. Haematologica $90612-624$.

Robbins RJ, Wan Q, Grewal RK, Reibke R, Gonen M, Strauss HW, Tuttle RM, Drucker W \& Larson SM 2013 Real-time prognosis for metastatic thyroid carcinoma based on 2-[18F]fluoro-2-deoxy-dglucose-positron emission tomography scanning. Journal of Clinical Endocrinology and Metabolism 91 498-505. (https://doi.org/10.1210/ jc.2005-1534)

Smit JWA, Elst der JPS-V, Karperien M, Que I, van der Pluijm G, Goslings B, Romijn JA \& van der Heide D 2009 Reestablishment of in vitro and in vivo iodide uptake by transfection of the human sodium iodide symporter (hNIS) in a hNIS defective human thyroid carcinoma cell line. Thyroid 10 939-943. (https://doi.org/10.1089/ thy.2000.10.939)

Sobin LH, Gospodarowicz MK \& Wittekind C 2009 TNM Classification of Malignant Tumours. Chichester, UK: John Wiley \& Sons.

Song YS, Lim JA, Min HS, Kim MJ, Choi HS, Cho SW, Moon JH, Yi KH, Park DJ, Cho BY, et al. 2017 Changes in the clinicopathological characteristics and genetic alterations of follicular thyroid cancer. European Journal of Endocrinology 177 465-473. (https://doi. org/10.1530/EJE-17-0456)

Sprick MR, Weigand MA, Rieser E, Rauch CT, Juo P, Blenis J, Krammer PH \& Walczak H 2000 FADD/MORT1 and caspase- 8 are recruited to TRAIL receptors 1 and 2 and are essential for apoptosis mediated by TRAIL receptor 2. Immunity 12 599-609. (https://doi. org/10.1016/S1074-7613(00)80211-3)

Tirrò E, Consoli ML, Massimino M, Manzella L, Frasca F, Sciacca L, Vicari L, Stassi G, Messina L, Messina A, et al. 2006 Altered expression of c-IAP1, survivin, and Smac contributes to chemotherapy resistance in thyroid cancer cells. Cancer Research 66 4263-4272. (https://doi.org/10.1158/0008-5472.CAN-05-3248)

Todaro M, Lombardo Y, Francipane MG, Alea MP, Cammareri P, Iovino F, Di Stefano AB, Di Bernardo C, Agrusa A, Condorelli G, et al. 2008 Apoptosis resistance in epithelial tumors is mediated by tumor-cellderived interleukin-4. Cell Death and Differentiation 15 762-772. (https://doi.org/10.1038/sj.cdd.4402305)

Trauzold A, Siegmund D, Schniewind B, Sipos B, Egberts J, Zorenkov D, Emme D, Röder C, Kalthoff H \& Wajant H 2006 TRAIL promotes metastasis of human pancreatic ductal adenocarcinoma. Oncogene $\mathbf{2 5}$ 7434-7439. (https://doi.org/10.1038/sj.onc.1209719)

Vaisman F, Carvalho DP \& Vaisman M 2015 A new appraisal of iodine refractory thyroid cancer. Endocrine-Related Cancer 22 R301-R310. (https://doi.org/10.1530/ERC-15-0300)

Verhagen AM, Ekert PG, Pakusch M, Silke J, Connolly LM, Reid GE, Moritz RL, Simpson RJ \& Vaux DL 2000 Identification of DIABLO, a mammalian protein that promotes apoptosis by binding to and
2018 Society for Endocrinology Published by Bioscientifica Ltd. Printed in Great Britain 
antagonizing IAP proteins. Cell 102 43-53. (https://doi.org/10.1016/ S0092-8674(00)00009-X)

Webb JL 1963 Enzyme and Metabolic Inhibitors. New York, NY, USA: Academic Press. (https://doi.org/10.5962/bhl.title.7320)

Werner TA, Tamkan-Ölcek Y, Dizdar L, Riemer JC, Wolf A, Cupisti K, Verde PE, Knoefel WT \& Krieg A 2016 Survivin and XIAP: two valuable biomarkers in medullary thyroid carcinoma. British Journal of Cancer 114 427-434. (https://doi.org/10.1038/bjc.2016.5)
Werner TA, Dizdar L, Nolten I, Riemer JC, Mersch S, Schütte SC, Driemel C, Verde PE, Raba K, Topp SA, et al. 2017 Survivin and XIAP - two potential biological targets in follicular thyroid carcinoma. Scientific Reports 7 11383. (https://doi.org/10.1038/s41598-01711426-3)

Zhang H-G, Wang J, Yang X, Hsu H-C \& Mountz JD 2004 Regulation of apoptosis proteins in cancer cells by ubiquitin. Oncogene $\mathbf{2 3}$ 2009-2015. (https://doi.org/10.1038/sj.onc.1207373)

Received in final form 22 December 2017

Accepted 9 January 2018

Accepted Preprint published online 9 January 2018 (c) 2018 Society for Endocrinology Published by Bioscientifica Ltd. 